\title{
Decadence and indifferentiation in the ideology of the Front National
}

\section{Dimitri Almeida}

Göttingen University

\begin{abstract}
Decadence, moral decay and national disintegration are obsessively recurrent themes in the narratives of the French radical right. This article explores the topos of decadence in the Front National's ideology through a content analysis of speeches and campaign material ranging from the 1980s until 2012. Beginning with an interpretation of decadence based on René Girard's discussion of persecution-legitimising texts, the article argues that the Front National's discourse on decadence revolves around the idea of a crisis of differences and an acceleration of exchanges presented as unnatural. This point is developed in relation to the role of sexuality in the party's profile and to the logics of historical development and political agency inherent to the Front National's understanding of decadence. Decadence, I argue, is indissociable from indifferentiation - the fear of seeing the disappearance of differences conceived as fundamental for the preservation of national order.
\end{abstract}

\section{Keywords}

decadence, Front National, ideology, otherness, radical right, scapegoating, sexuality

\section{Introduction}

Studies on extremist ideologies generally converge in the assessment that the diagnosis of a crisis constitutes a central leitmotiv in ultra-nationalist, fascist and radical right narratives. Most often, the qualification of a perceived crisis draws from the idiom of fin-de-siècle cultural pessimism to construct the holistic image of a decay of civilisation. In his analysis of the origins of fascist ideology in France, Zeev Sternhell (1983) identifies the topos of social, intellectual and economic decadence as a central element of proto-fascist and fascist doctrines. In his path-breaking contributions to the study of fascist ideologies, Roger Griffin places the myth of national decadence at the core

\section{Corresponding author:}

Dimitri Almeida, Department of Romance Philology, Göttingen University, Humboldtallee 19, 37073 Göttingen,

Germany.

Email: dimitri.almeida@phil.uni-goettingen.de 
of a minimal definition of fascism. Following this line of thought, every fascist Weltanschauung shares a 'palingenetic ultra-nationalism' - a belief that the national community will be reborn 'phoenix-like after a period of encroaching decadence which all but destroyed it' (Griffin, 1991: 38 , emphasis in the original). The centrality of the decadence theme in ultra-nationalist and fascist ideologies from the late nineteenth to the mid-twentieth century is further highlighted by case studies devoted to individual authors and movements. Eugen Weber's (1962) seminal study on Action Française stresses the importance of the notion of decadence in the political writing of Charles Maurras in which the French defeat of 1870 and declining birth rates appear as irrefutable evidence of France's decay. Analyses of the contemporary radical right in France suggest a discursive continuity in the portrayal of a national community afflicted by decadence and moral decay (Winock, 1990; Hainsworth, 1992; Chebel d'Appollonia, 1996; Shields, 2007). However, despite the observed continuity in the invocation of decadence in post-fascist ideologies, our theoretical understanding of its meanings and functions remains limited. This article seeks to redress this gap by developing a framework for understanding the topos of decadence in radical right ideology based on an analysis of the Front National (FN). My main argument is that decadence is conceived as a process of vanishing differences and represents the central ideological axiom from which the FN's core values and beliefs are derived.

My argument unfolds in four sections. I begin by elaborating on the notion of decadence through an interpretation of the term based on René Girard's analysis of scapegoating in persecution-legitimising texts. Second, I argue that the FN's discourse on decadence revolves around the idea of a crisis of differences and an acceleration of unnatural exchanges. I develop and illustrate this point in relation to the role of sexuality in the FN's narratives on French decadence. Third, I analyse the logics of historical development and political agency inherent to the concept of decadence used in the party's programmatic profile. Finally, I conclude with a general discussion on whether Marine Le Pen's accession to the party leadership represents a change of paradigm in the FN's ideology.

\section{Decadence as a crisis of differences}

In Le Bouc émissaire, René Girard (1982) identifies a set of structural rules that govern the designation of surrogate victims and the violence perpetrated against them. According to Girard (1972), the cultural order of human societies can be conceived as a system of differences that regulates exchanges between the members of a community. The preservation of differences is thus conceived as a necessary condition for the survival of any group. At the origins of persecutions lies a crisis that persecutors portray as a fundamental and overarching dissolution of the social bond resulting from deliberate actions committed by individual or collective actors. ${ }^{1}$ The crisis at the heart of scapegoating is fundamental in the sense that it is understood as a crisis of differences, a process blurring basic distinctions that allow a social order to function. The neutralisation of differences manifests itself through a state of social anomy characterised by an intensification and acceleration of hostile exchanges between members of a community. The crisis is overarching in that it affects every aspect of private and social life. Girard illustrates these points by drawing on Guillaume de Machaut's Le Jugement du Roy de Navarre. In this mid-fourteenth-century poem, a case of love casuistry is preceded by the narrator's reflections on the devastations surrounding the spread of the plague. The crisis is described through a scenario of meteorological aberrations (bleeding skies) and natural catastrophes (earthquakes). At the core of the crisis is a solar eclipse that abolishes the fundamental distinction between night and day followed by a comet predicting fire and murder (Machaut, 1908: verse 165). Although later in the text Machaut conceives the plague in its epidemiological dimension, the first attempt to explain the origin of this phenomenon introduces a 
conspiracy theory blaming Jews for having poisoned wells, rivers and fountains and having killed, as a result, 'dis fois cent mille' (1908: verse 225). Machaut narrates how, following the divine revelation of this 'traïson', Jews were massacred in the most violent of ways (1908: verse 231).

Girard's (1982) reading of Machaut concentrates on the naivety of an account that does not attempt to hide the rationale of scapegoating because its author is not aware of the logic of collective violence against innocent victims that guides his narrative. According to Girard's understanding of the latent structure of scapegoating, persecutory texts feature some or all of the following stereotypes of persecution: (i) a crisis, which is experienced as a process of cultural disintegration induced by the abolition of fundamental differences; (ii) accusations that relate the crisis to transgressions whose distinguishing essence pertains to the suppression of fundamental differences; ${ }^{2}$ (iii) the designation of victims according to specific physical, social, religious or behavioural markers; and (iv) the physical elimination or displacement of the scapegoat in the belief that this will restore the status quo ante. Before returning to the three latter stereotypes, I first delve into the idea of a crisis of differences, because, as I shall argue, it is precisely in the notion of indifferentiation that the defining trait of decadence in the FN's ideology rests.

The type of decadence described in the political writings and speeches of the FN is not restricted to a particular arena of human activity, but concerns every single domain of social life. In this sense, decadence is a single, uniform and all-encompassing process of decay. The notion of holistic decadence functions as a prism that structures the party's programmatic profile. Its heuristic value is perhaps most explicit in the party's manifesto in view of the 2002 presidential and legislative elections (Front National, 2001). This unusually long document of over 400 pages draws a terrifying picture of a country afflicted by a generalised crisis. The description of this state of decay is structured in two non-sequential stages: (i) the enumeration of social phenomena and pathologies (insecurity, unemployment, drug abuse, epidemics of infectious diseases, etc.) presented as exterior manifestations of an underlying decline, and (ii) the depiction of this deeper crisis - a crisis interpreted as the destabilisation of the core values of civilisation - the beautiful, the good and the truthful ('le Beau, le Bien, le Vrai', capitalised in the original). This essentialist conception is lengthily exposed in the section of the manifesto devoted to cultural policy (Front National, 2001: 390-402). The text reproduces longer passages of the 1993 manifesto, in addition to the central arguments of a speech given by Bruno Gollnisch (Jean-Marie Le Pen's former right arm and the unsuccessful candidate for the FN's presidency against Marine Le Pen in 2011) at the 1996 summer school of the nationalist-Catholic organisation Renaissance Catholique. In this speech, Gollnisch delineates a minimalist grammar of societies stating that each civilisation is built on the acceptance that beauty, truth and good exist as absolute and objective values. National communities then develop their idiosyncratic traits according to their territory and history, French civilisation having forged its specific character through the synthesis of Latin, Celtic and Germanic elements, the embracing of Christianity, and a process of colonial expansion understood as a messianic project (Gollnisch, 1997). In the manifesto, this orthogenetic narrative of French civilisation is purged of its explicit racial, Christian and colonialist premises and reduced to the claim that France has acquired its unique character by recognising objective beauty as a state-sanctioned paradigm of cultural practices. This objective and immutable beauty forms the normative basis for a hierarchy of cultural expressions. In aesthetic terms, the crisis to which France is argued to have fallen prey is imputed to a new model of culture 'qui sacralise la laideur' (Front National, 2001: 391 ) in a process of totalitarian uniformisation promoted by the state. Rather than an inversion of values, the scenario depicted in the manifesto is one of indifferentiation. The differential order collapses as ugliness and beauty become indistinguishable, with Mozart and the stained-glass windows of Chartres Cathedral placed at the same level as rap music and Buren's Les Deux Plateaux (Front National, 2001: 391). The diagnosis of vanishing differences represents the discursive 
thread that binds together the FN's descriptions of the status quo. Just as aesthetic differential patterns are annihilated in a crisis of differences, so are all moral values.

The social dysfunctions enumerated in the party's texts depict a state of extreme violence whose origins lie in a deliberate state policy aimed at letting moral boundaries between good and evil disappear (Le Pen, 2007b). ${ }^{3}$ Since its manifesto for the 1986 elections (Le Pen, 1985a), the FN's programmatic documents and campaign speeches include long sections devoted to the topic of insecurity that link the alleged rise of criminality to both immigration and a moral indifferentiation promoted by an alleged change of paradigm in criminal justice accused of victimising criminals while criminalising victims and letting the latter fall prey to violence and fear (e.g. Le Pen, 1985b; Le Pen, 2007a). The general climate of insecurity within French society depicted in the party's manifestos bear striking parallels to the notion of immediate reciprocities introduced by Girard to characterise the crisis of differences in persecution-legitimising texts. Building upon the work of Marcel Mauss, Girard considers social life as a system of exchanges which maintains stable patterns of social organisation. The reciprocal character of social life is concealed by the delay between the constituent acts of an exchange. Indifferentiation, as the disruption of social organisation, is experienced as the acceleration of exchanges between members of a community and the pervasiveness of hostile reciprocities (Girard, 1982: 13). The pattern of increasingly rapid and intense violent exchanges is a structuring motive in the FN's description of French decadence as a state characterised by the multiplication of crimes, the trivialisation of abortion, generalised corruption and collusion between political and media elites. However, the crucial role of immediate reciprocities is perhaps most explicitly conveyed in the link the party establishes between decadence and sexuality.

\section{Decadence and sexuality}

The mimetic violence at the core of Girard's understanding of the crisis of differences consists in the unmediated acceleration of violent reciprocities, whose character can often be of a sexual nature, because, as Girard argues, 'L'excitation sexuelle et la violence s'annoncent un peu de la même façon' (Girard, 1982: 61). As a direct and indirect source of indifferentiation and thus of destabilisation of the cultural order, sexuality is a fundamental target of decadence-centred discourse. In La France est de retour, Jean-Marie Le Pen establishes an explicit link between sexuality and an unilinear evolutionist theory of civilisation by stating: 'je pense que la chance qui était donnée aux natifs des pays tempérés d'avoir une sexualité relativement retardée expliquait sans doute le développement intellectuel exceptionnel de nos civilisations' (Le Pen, 1985b: 168). The causal relationship between sexual moderation and level of civilisation suggested by Le Pen is probably inspired by the theory on the origin of civilisations postulated by the physician and Nobel laureate Alexis Carrel, whose work is regularly quoted in FN's older literature (e.g. Le Pen, 1989a: 133-4; Front National, 2001: 6). In his best-selling book, L'Homme, cet inconnu, which advocates the perfectibility of the human species through eugenics, Carrel (1935: 168) explains that the repression of sexual impulses favours intellectual and civilisational development. ${ }^{4}$ From a Girardian perspective, the references to sexual restraint present in the programmatic profile of the radical right are not mere social conservative expressions of sexual bigotry, but reflect a deeper belief that limits imposed on sexual exchanges form a barrier against mimetic rivalry and thus represent a source of preservation of the cultural order. This premise allows a better understanding of the prominence of sexual motives in the FN's discourse on decadence. The topos of the acceleration of sexual reciprocities is introduced in several of the speeches and writings of Jean-Marie Le Pen and is mostly associated with evocations of the lasciviousness of non-European immigrants. In 1984, Le Figaro quoted a speech by Le Pen, in which he allegedly warned: 'Demain les immigrés 
s'installeront chez vous, mangeront votre soupe et coucheront avec votre femme, votre fille ou votre fils' (quoted in Mayer, 1999: 129). As Michael Billig (1990) observed, by associating immigration with the spread of promiscuity, Le Pen invokes the idea that immigrants represent a threat to the virtuous chastity of the nation. The threat is made tangible through two scenarios.

The first scenario contrasts the declining fertility of 'French' women to soaring immigrant birth rates. In a speech devoted to pro-natalist policies during the 2007 presidential election campaign, Le Pen foretold a 'substitution de population', arguing that the total fertility rate in France was in large part due to the number of births among immigrant women as supposedly illustrated by the fact that the Seine-Saint-Denis (a département with a large concentration of citizens from postcolonial ethnic minorities) displayed the highest fertility rate in France (Le Pen, 2007a). The speech blended traditionalist pro-natalist elements with the differentialist fundaments of the nouvelle droite by presenting intermarriage and the birth of children with one parent of foreign origin as further proof of a demographic crisis. The omnipresence of the spectre of métissage suggests that the FN's discourse on French demographics is less about birth rates than about the fear of ethnic indifferentiation. As Le Pen declared during his annual speech in honour of Joan of Arc in 2000: 'Rappelons-nous les nouvelles et apocalyptiques menaces qui pèsent sur notre pays ... le métissage complet imposé à notre peuple, par le fait d'une immigration massive et d'une dénatalité monstrueusement organisée, la disparition de notre civilisation' (Le Pen, 2000b). Low total fertility rates and immigration are presented here as part of a plot aimed at the demographic restructuring of France.

The second scenario associated with the acceleration of sexual reciprocities triggered by immigration is the spread of mimetic contagion in the form of sexually transmitted infections. 'Pure' sexuality restricted to its procreative function is contrasted with impure forms of sexuality. The FN was the first political formation in France to politicise the issue of HIV in a series of much-quoted statements, which included an appeal to contain the infection through the establishment of 'sidatoriums' and the spreading of false information on the modes of transmission of the virus (Mathiot, 1992). Although, as Guy Birenbaum (1992: 306-7) remarks, the political instrumentalisation of AIDS by the FN was weakened by the emergence of a scientifically grounded discourse, the party pursued its campaign of tying the virus to immigration. A pamphlet distributed before the 1995 local election in Paris included among several unfounded allegations on the effects of immigration the statement that 67 per cent of heterosexual HIV-positive persons living in France were of sub-Saharan or Caribbean origin (Front National, 1995). More recently, in a speech titled 'Guerre et paix', Le Pen warned that immigration was a key factor in the proliferation of the virus (Le Pen, 2006b).

The pervasiveness of sexual motives in the FN's conception of decadence extends to homosexuality, which is presented as a symptom of a wider process of decay. Although homophobic statements had been present in the party's profile since its creation, homosexuality began to feature more systematically in the party's profile after the debates on the law instituting civil unions during the Jospin government (1997-2002). Cas Mudde's (2000: 189) study on the ideology of the extreme right associates homophobia with a social conservative focus on traditional morality. Peter Davies (1999: 132) provides a more detailed account, emphasising the dual function of homosexuality in the FN's discourse where homosexual relations represent the infringement of a natural order and an additional factor endangering the demographic survival of the nation. While the party's stance is indeed structured by the idea that homosexuality represents an ontological violation of a natural hetero-normativity and a behavioural deviance from procreational imperatives, the discursive thread that weaves together the FN's references to homosexuality relates to its contagiousness. Homosexuality is represented as a threat against the survival of civilisation inasmuch as it may 'contaminate' other members of the community. The contagion described in 
the 2002 party manifesto is presented as a process initiated by lobby groups and actively supported by the state with the aim of imposing 'leurs comportements déviants en modèle social normatif' (Front National, 2001: 42). As Davies (1999: 132) notes, the FN uses homosexuality as an accusation against political elites for their failure to enforce public morality through the regulation of social behaviour. More specifically, the accusation is that, rather than being contained as a deviant act, homosexuality has spread to become state-sanctioned behaviour. In a speech during the 2010 regional election campaign, Le Pen warned that French decadence would not last as long as the decadence of the Roman Empire by referring to the spread of sexual freedom and the elevation of homosexuality to the status of a 'noblesse du temps' as unequivocal signs of an advanced state of decay (Le Pen, 2010). Girard's observation that persecutory texts associate the mimetic crisis with the propagation of sexual exchanges conceived as illicit is applicable to the party's representations of the contagiousness of homosexuality. The depiction of homosexuality as a miasma spreading through society can be related to Judith Butler's (1997: 103-26) analysis of the 'don't ask, don't tell' policy where the explicit recognition of homosexuality appears as the transferable violation of a taboo, something whose very utterance may unleash a wave of contagion. The representations of homosexuality are characterised by acute forms of violence. As Lesselier (1988) notes, the fact that the party's 1985 manifesto covered homosexuality in the chapter devoted to security and criminality is revealing in this regard. Even more revealing is the juxtaposition of gay pride parades, paedophilia and pornography as forms of deviant behaviour propagated in French society (Le Pen, 2000a). Here, 'uttered' homosexuality in the form of public demonstrations or other forms of 'prosélytisme homosexuel' (Le Pen, 2003) is related to the spread of acute violence against children and unmediated sexuality - two phenomena posing a threat to the subsistence of the cultural order. Although the party has reframed its opposition to homosexuality in apparently more republican terms through the refusal of communautarisme, the party's manifestos of 2002, 2007 and 2012 continued to present homosexuality as a violenceengendering phenomenon by including statements on homosexuality blended with policy pledges on the need to protect children from pornography, paedophilia, human trafficking and suicide (Front National, 2001, 2007; M Le Pen, 2012a).

In persecutory texts, the depiction of a social and cultural crisis is the first phase in a narrative that proceeds with the identification of scapegoats and the appeal to neutralise the surrogate victims and culminates in the prefiguration of the return to the status quo ante. In the following section, I concentrate on how the portrayal of decadence in the FN's discourse integrates a causal account on the origins of a crisis and the path to recovery.

\section{Decadence, history and political agency}

From Giambattista Vico's Scienza nuova (1744) to Ernst von Lasaulx's Philosophie der Geschichte (1856), Oswald Spengler's Der Untergang des Abendlandes (1921-2) and Arnold Toynbee's (1939) study on the genesis, breakdown and disintegration of civilisations, decadence is typically understood as a natural stage in the evolution of civilisations - whether it takes the form of a relapse to a previous stage (Vico), an inevitable total collapse (Lasaulx and Spengler), or a downfall that can perhaps be avoided (Toynbee). Studies devoted to the cultural history of the notion of decadence emphasise the intimate connection between decadence and attempts to identify law-like regularities in the rise and fall of civilisations (Swart, 1964; Gilman, 1979; Pauen, 1997). As Neville Morley (2004) shows in his discussion of the historicising logics attached to the concept of decadence as a theory of history, the idea of decadence suggests three different attitudes towards the past: (i) nostalgic references to a golden age in which the symptoms of decadence did not yet prevail; (ii) the equation of present decadence with a previous analogous state; and (iii) the 
invocation of the past in order to predict what will ensue from present decadence and to develop a strategy for renewal.

The topos of decadence developed in the FN's discourse displays all three elements identified by Morley. The logic of historical development inherent to the party's conception of decadence is one of cyclicality. The idea of decadence as a recurrent state of crisis has played a central role in every speech pronounced by Jean-Marie Le Pen in the yearly commemoration of Joan of Arc organised by the party each 1 May. The speeches generally begin with a digression on the state of France during the Hundred Years War before the siege of Orleans. The atrocities of the war, as narrated by Le Pen, are only surpassed in horror by the Treaty of Troyes (the agreement stipulating that the French throne would pass to Henry V of England or his heirs upon the death of Charles VI). At this point, the speeches emphasise the supposedly striking parallels between the situation of France in the 1420s and state of the nation in present times. The Treaty of Troyes and the Treaty of Maastricht are presented as parts of the same plot by perfidious French elites to abandon France's independence. Le Pen expounds his biography of the Maid of Orleans by presenting her as the path to rescue the nation from decadence: just as Joan of Arc had to face calumny, treachery and persecution, so too has the FN been the martyr of French independence against those eager to let France disappear as a sovereign nation (e.g. Le Pen, 1998, 2000b, 2006a). Here, the past acquires a distinctive prescriptive and explicative function - a function characteristic of mythical discourse. As Ernst Cassirer (1925: 133-6) argues in the volume of his Philosophy of Symbolic Forms devoted to mythical thought, in myth, present events are regarded as explained as soon as a past occurrence can be related to the present. Past phases of decadence as a sufficient explanation for a present crisis abound in the FN's programmatic profile. The cyclical conception of France's history as a repetition of past events is particularly salient in a campaign video for the 2002 presidential election campaign. The short clip consists of a series of images representing war and desolation intercalated by a particular date of French history forming the sequence ' $732,1815,1870,1914,1940$ ', followed by an off-camera voice commenting: 'La France fut de nombreuses fois envahie, mais elle trouva toujours sur son chemin un homme qui conduisit à sa libération. Même dans les pires situations les Français ont eu raison de ne pas désespérer' (Front National, 2002). The video continues with the juxtaposition of two years (1940 and 1970) and the warning that France has again arrived at a stage in history when it is confronted with an invasion (immigration). The message of the campaign clip is free from ambiguities: France's historical development can be reduced to the repetitive sequence of decadence, national reaction and salvation, the latter being embodied in a providential man, who, in this situation, is Jean-Marie Le Pen himself.

There is an inherent tension in the FN's narratives on decadence between a mechanistic conception and a causal account of decadence based on political agency. On the one hand, decadence is understood as an ineluctable crisis breaking out at fairly regular intervals throughout French history. On the other hand, the FN frames decadence as the result of a deliberate and premeditated plan by unscrupulous elites devoted to an anti-national cause. The party solves this paradox in two steps: the FN begins by developing a Manichean conception of civilisation that relies on the binary pair 'civilisation v. barbarism'. The FN's ideology conceives decadence as a process exogenous to civilisation and not as a by-product of modernity. This conception effectively isolates and exteriorises decadence-engendering elements inherent to the usages of the term 'civilisation' identified in Jean Starobinski's (1993) semantic history of the concept. ${ }^{5}$ As such, the notion of decadence developed by the party stands in contrast to cultural pessimist and deterministic accounts that describe decadence as an inevitable consequence of developments that are beyond the realm of human agency. Second, the FN's discourse on decadence bears a distinct criminological dimension inasmuch as the party presents decadence as a form of violence intentionally inflicted on the nation. Decadence, in the view of the FN, is thus not a natural phase in the lifespan of civilisations, but the 
intended result of crimes of indifferentiation against the nation meticulously planned by political and economic elites (Le Pen, 1997).

The logic by which the FN designates the perpetrators accused of being responsible for the crisis follows the patterns of scapegoating identified by Girard. The surrogate victims are chosen according to specific traits defined by religion, ethnicity, sexual orientation or political preferences. The most prevalent and persistent form of scapegoating articulated in the party's publications and speeches is directed toward groups or individuals considered to be constituent parts of 'the political elite'. Throughout the party's history, this anti-establishment rhetoric has regularly been combined with verbal anti-Semitic and anti-Masonic hostility, for example when JeanMarie Le Pen described 'le lobby mondialiste' allegedly responsible for the creation of an antinational climate as composed of the Freemasonry, the Trilateral Commission and other international groups, including 'l'internationale juive' (Le Pen, 1989b). Since the presidential election campaign of 2007, a campaign managed by Marine Le Pen and placed under the sign of dédiabolisation, the numerous references to Masonic conspiracies, which were still present in the party's 2002 manifesto, have been withdrawn from the party's electoral platform. What remained is a vociferous anti-establishment campaign against elites accused of wanting France to disappear. In his speeches, Jean-Marie Le Pen explicitly draws on the historical vocabulary of the French radical right by using the distinction coined by Maurras (1916) between the 'pays légal' (the establishment) and the 'pays réel' (the people) as well as the Maurrassian term 'antiFrance' to designate the internal enemies of the nation (e.g. Le Pen, 2005). Immigrants in general and Muslims in particular are partly presented as secondary scapegoats - secondary in the sense that they are described as mere instruments in the hands of an oligarchy for the purposes of reducing labour costs and diluting national identity (Le Pen, 2007c; M Le Pen, 2012c). Except for these vague remarks on how immigration is supposed to serve the interests of global capitalism, the party's narratives do not establish a clear case in the accusations made against political and economic elites. The meticulousness by which elites are argued to have planned France's decadence contrasts with an almost complete lack of plausible motives. Instead, the FN constructs a narrative of malevolent elites whose hatred of France is the prime motive for precipitating the country into a state of decadence. Referring to the introduction of the common currency as the worst act of collaborationism in French history and to the alleged anti-national subversion of history curricula at French schools, Jean-Marie Le Pen explained that these phenomena were part of the same plan to deprive the French of their history and collective memory (Le Pen, 1998). Reacting to the wave of protests against his presence in the second round of the 2002 presidential election, he accused politicians of the 'establishment' of only opposing the FN 'parce qu'ils exècrent la nation qu'ils ont trahie' (Le Pen, 2002). Similarly, Marine Le Pen's antiestablishment rhetoric revolves around the idea that elites despise the people and the nation (M Le Pen, 2012b). In addition to vivid characterisations of the hatred political and economic elites supposedly bear towards France, further charges against opponents are made by referring to accusations of criminal transgressions of the natural order. Among these accusations, incest-like interactions play a prominent role, as illustrated by the description of French political and media elites made in the party's 2002 manifesto which evokes an orgiastic self-reproductive system of 'dynasties bourgeoises' who exchange public posts, spouses and mistresses (Front National, 2001). The accusations against elites follow the pattern defined by Girard and found in the party's homophobic and anti-immigration discourse: a pattern consisting in stereotyped charges of crimes that destabilise the cultural order because they unleash a wave of unnatural exchanges.

Understanding the link between indifferentiation and decadence in the FN's discourse is not a self-serving exercise in that it allows us to explore less frequent ways of conceptualising radical right narratives. One important implication of focusing on decadence as a core ideological feature 
providing the basis for scapegoating is the idea that the surrogate victims are selected according to the alleged threat they pose to the differential order. The FN's persecution-legitimising discourse is thus not based on a fear of otherness, but on its contrary - the anguish of seeing the constitutive differences of the social order promoted in the party's ideology disappear. To rephrase Pippa Norris's (2005: 132) characterisation of the radical right, its 'signature issue' may not be 'the threat of the other', but rather the threat of seeing what differentiates the one from the other disappear.

\section{Decadence under the sign of dédiabolisation}

In 1989, a year marked by the commemorations of the bicentennial of the French Revolution, JeanMarie Le Pen gave a speech in his home town La Trinité-sur-Mer in which he depicted the 1789 Declaration of the Rights of Man as the origin of French decadence on the grounds that it denies the fundamental differences on which communities are built (Le Pen, 1989c). In today's bleu marine FN, this explicit link between decadence and indifferentiation articulated through the clearcut rejection of the principle of equality would be unthinkable. In her speeches during the 2012 presidential election campaign, Marine Le Pen has consistently avoided the term 'decadence', referring instead to an 'inversion des valeurs' and to a 'désordre national' (M Le Pen, 2012d). With the party's effort to enter a realm of republican acceptability, the evocation of pre-revolutionary golden ages has given way to ostentatious displays of republicanism. Explicit references to the pantheon of the French radical right have been replaced by quotations from Michelet, Ferry, Zola and Jaurès. Attacks on political elites accused of having turned against the nation rely on an idealised Third Republic concerned with educational excellence and authority and Gaullist times when elites were uncorrupted and unwilling to abdicate national sovereignty (e.g. M Le Pen, 2011b; 2012b). Most importantly, under Marine Le Pen, the FN has integrated new programmatic foci that convey the impression of a systematic de-radicalisation of the party's profile. Among these innovations, Marine Le Pen attempts to project an image of her party as the sole authentic defender of laïcité stand out, considering that the FN previously displayed a small, but influential Catholic fundamentalist wing gathered around Bernard Antony's Chrétienté-Solidarité and that its pre-2007 programmes did not mention laïcité. However, a close inspection of the party's newly found devotion to laïcité suggests that it is merely deployed as a narrative bearing few resemblances to the spirit of the 1905 law and is aimed at legitimising exclusionary measures against Muslims living in France. As I have argued elsewhere (Almeida, 2013), rather than an all-encompassing process of moderation, the 'new' $\mathrm{FN}$ has essentially reframed prior positions in more acceptable terms without substantially modifying core policy pledges, combined with a strategy of radicalisation in certain policy domains and a selective de-radicalisation in others. ${ }^{6}$

While Marine Le Pen has indubitably brought about a modernisation of the FN's discourse, the traditional conception of a moral crisis caused by deliberate crimes against the differential order has not disappeared with her accession to party's presidency. In her presidential campaign speeches, she has made recurrent use of accounts of scapegoating focused on conspiracies organised by minorities supported by influential political circles, for instance when she claimed that the French were unknowingly being forced to consume halal meat (M Le Pen, 2011a). To a certain extent, a division of labour has been established, with Marine Le Pen and other party cadres committed to a modernisation of the party's image (such as the FN's vice-president and former Chevenementist Florian Philippot) at the front of the party's external communication, and an old guard constituted among other by Jean-Marie Le Pen and Bruno Gollnisch (both of whom have kept key functions within the party) signalling continuity with the old FN. ${ }^{7}$ The organisation of the party's ceremony in honour of Joan of Arc in 2012 with an opening speech by Jean-Marie Le Pen focused on la pucelle as an inspiration to save France from decadence, followed by a more prosaic campaign 
speech by Marine Le Pen, is illustrative of this distribution of roles, and shows that the FN has not witnessed a radical break with the differentialist roots that structure its ideology.

\section{Funding acknowledgement}

This research received no specific grant from any funding agency in the public, commercial, or not-for-profit sectors.

\section{Notes}

1. I use the term persecution in its broadest sense to refer to any form of collective violence (physical or discursive) against an individual or a group.

2. Girard (1982: 20-1) gives several examples of accusations pointing to crimes of indifferentiation. These include Oedipus's parricide or Marie Antoinette's alleged incest with her son. In Machaut's narrative poem, the poisoning of water sources that had been 'cleres et seinnes' (Machaut, 1908: verse 220 ) is in its essence a crime against a system of differences that transforms a source of life into a source of death.

3. Most of the speeches quoted in this article are no longer available on the FN's homepage (www.frontnational.com). If necessary, they can be obtained from the author.

4. On the influence of Alexis Carrel on the FN's ideology, see Reggiani (2007).

5. Jean-Marie Le Pen's (2011) characterisation of his mission as 'le combat immémorial de la Civilisation contre les Barbares' illustrates this exteriorisation of decadence.

6. The partial policy radicalisation of the FN under Marine Le Pen is particularly salient in the field of European and monetary policy. In 2012, the party manifesto featured the pledge to reintroduce a national currency and measures that amounted to a de facto withdrawal from the European Union (M Le Pen, 2012a). Both positions were absent from the party's 2007 manifesto (Front National, 2007).

7. Note that there is also a younger generation of FN cadres committed to decadence-centred narratives such as the leader of the Front National de la Jeunesse, Julien Rochedy, whose first book (2010) provides a differentialist account of French decadence in the tradition of the nouvelle droite.

\section{References}

Almeida D (2013) Towards a post-radical Front National? Patterns of ideological change and dédiabolisation in the French radical right. Nottingham French Studies 52(2): 167-76.

Billig M (1990) Psychological aspects of fascism. Patterns of Prejudice 24(1): 19-31.

Birenbaum G (1992) Le Front national en politique. Paris: Balland.

Butler J (1997) Excitable Speech: A Politics of the Performative. New York: Routledge.

Carrel A (1935) L'Homme, cet inconnu. Paris: Plon.

Cassirer E (1925) Die Philosophie der symbolischen Formen, vol. 2: Das mythische Denken. Berlin: Bruno Cassirer.

Chebel d'Appollonia A (1996) L'Extrême-droite en France: de Maurras à Le Pen. Brussels: Éditions Complexe.

Davies P (1999) The National Front in France: Ideology, Discourse and Power. London: Routledge.

Front National (1995) Le Front national pour Paris ville française. Leaflet distributed during the municipal election campaign.

Front National (2001) Pour un avenir français: Le programme de gouvernement du Front national. Paris: Éditions Godefroy de Bouillon.

Front National (2002) Immigration - invasion. Video clip available at the 2002 campaign site: www.le-pen. info (accessed 3 June 2002).

Front National (2007) Programme de gouvernement de Jean-Marie Le Pen. Paris: Front National.

Gilman R (1979) Decadence: The Strange Life of an Epithet. New York: Farrar Straus \& Giroux.

Girard R (1972) La Violence et le sacré. Paris: Grasset.

Girard R (1982) Le Bouc émissaire. Paris: Grasset \& Fasquelle. 
Gollnisch B (1997) Les Valeurs de la civilisation française. In: Renaissance Catholique (ed.) Qui a peur du baptême de Clovis? Actes de la Ve Université d'Été de Renaissance Catholique à Avenay-Val-d'Or. Paris: Éditions Renaissance Catholique, pp. 245-68.

Griffin R (1991) The Nature of Fascism. London: Routledge.

Hainsworth P (1992) The extreme right in post-war France: the emergence and success of the Front National. In: P Hainsworth (ed.) The Extreme Right in Europe and the USA. New York: St Martin's Press, pp. 29-60.

Le Pen J-M (1985a) Pour la France: programme du Front national. Paris: Albatros.

Le Pen J-M (1985b) La France est de retour. Paris: Carrère.

Le Pen J-M (1989a) L'Espoir, entretiens avec J. P. Gabriel et P. Gannat. Paris: Albatros.

Le Pen J-M (1989b) Interview. Présent, 11 August, p. 4.

Le Pen J-M (1989c) Speech at La Trinité-sur-Mer. 26 August.

Le Pen J-M (1997) Speech at the 17th Bleu-Blanc-Rouge Festival. 26 September.

Le Pen J-M (1998) Speech at the commemoration of Joan of Arc. 1 May.

Le Pen J-M (2000a) Closing speech at the 11th Front National Congress. 30 April.

Le Pen J-M (2000b) Speech at the commemoration of Joan of Arc. 1 May.

Le Pen J-M (2002) Speech at the commemoration of Joan of Arc. 1 May.

Le Pen J-M (2003) Speech at the Front National's National Council. 20 September.

Le Pen J-M (2005) Speech at the 22nd Bleu-Blanc-Rouge Festival. 9 October.

Le Pen J-M (2006a) Speech at the commemoration of Joan of Arc. 1 May.

Le Pen J-M (2006b) Speech in Herbiers. 22 October.

Le Pen J-M (2007a) Speech in Paris. 21 January.

Le Pen J-M (2007b) Speech in Yvetot. 27 January.

Le Pen J-M (2007c) Speech in Lille. 25 February.

Le Pen J-M (2010) Speech in Paris. 13 February.

Le Pen J-M (2011) Speech in Lyon. 11 March.

Le Pen M (2011a) Speech in Metz. 12 December.

Le Pen M (2011b) Speech in Nice. 11 September.

Le Pen M (2012a) Le Projet de Marine Le Pen. Paris: Front National.

Le Pen M (2012b) Pour que vive la France. Paris: Éditions Grancher.

Le Pen M (2012c) Speech in Bordeaux. 22 January.

Le Pen M (2012d) Speech in Toulouse. 5 February.

Lesselier C (1988) The women's movement and the extreme right in France. In: G Seidel (ed.) The Nature of the Right: Feminist Analysis of Order Patterns. Amsterdam: John Benjamins, pp. 173-84.

Machaut G (1908) Le Jugement du Roy de Navarre. In: E Hoepffner (ed.) Euvres de Guillaume de Machaut, vol. 1. Paris: Firmin-Didot, pp. 137-282.

Mathiot P (1992) Le Sida dans la stratégie et la rhétorique du Front National. In: P Favre (ed.) Sida et politique, les premiers affrontements: 1981-1987. Paris: L'Harmattan, pp. 189-201.

Maurras C (1916) Enquête sur la monarchie, 9th edn. Paris: Nouvelle Librairie Nationale.

Mayer N (1999) Ces Français qui votent FN. Paris: Flammarion.

Morley N (2004) Decadence as a theory of history. New Literary History 35(4): 573-85.

Mudde C (2000) The Ideology of the Extreme Right. Manchester: Manchester University Press.

Norris P (2005) Radical Right: Voters and Parties in the Electoral Market. Cambridge: Cambridge University Press.

Pauen M (1997) Pessimismus: Geschichtsphilosophie, Metaphysik und Moderne von Nietzsche bis Spengler. Berlin: Akademie Verlag.

Reggiani AH (2007) God's Eugenicist: Alexis Carrel and the Sociobiology of Decline. New York: Berghahn Books.

Rochedy JL (2010) Le Marteau: déclaration de guerre à la décadence moderne. Paris: Praelego.

Shields JG (2007) The Extreme Right in France: From Pétain to Le Pen. London: Routledge.

Spengler O (1921-2) Der Untergang des Abendlandes: Umrisse einer Morphologie der Weltgeschichte, 2 vols. Munich: Beck. 
Starobinski J (1993) Blessings in Disguise; or, the Morality of Evil. Cambridge, MA: Harvard University Press.

Sternhell Z (1983) Ni droite ni gauche: l'idéologie fasciste en France. Paris: Seuil.

Swart K (1964) The Sense of Decadence in Nineteenth Century France. The Hague: Nijhoff.

Toynbee AJ (1939) A Study of History, vols. IV-VI. Oxford: Oxford University Press.

Vico G (1744) Principi di scienza nuova d'intorno alla comune natura delle nazioni. Naples: Stamperia Muziana.

Von Lasaulx E (1856) Neuer Versuch einer alten auf die Wahrheit der Thatsachen gegründeten Philosophie der Geschichte. Munich: Literarisch-Artistische Anstalt.

Weber E (1962) Action Française: Royalism and Reaction in Twentieth Century France. Stanford, CA: Stanford University Press.

Winock M (1990) Nationalisme, antisémitisme et fascisme en France. Paris: Seuil.

\section{Author biography}

Dimitri Almeida is Lecturer in French and Francophone Area Studies in the Department of Romance Philology at the University of Göttingen. He has published articles on the European radical right with a particular focus on the French case and is author of The Impact of European Integration on Political Parties: Beyond the Permissive Consensus (2012). 